\title{
IAMJ
}

INTERNATIONAL

AYURVEDIC

MEDICAL JOURNAL

\section{HYPERTENSION: AN AYURVEDIC PERSPECTIVE}

\section{$\underline{\text { Anshika Rao }}$}

M.D. Scholar, P.G. Department of Rachna Sharira, R.A.C., Lucknow, (U.P.), India

Corresponding Author: anshikaraolko@gmail.com

\section{https://doi.org/10.46607/iamj2409082021}

(Published Online: August 2021)

Open Access

(C) International Ayurvedic Medical Journal, India 2021

Article Received: 06/07//2021 - Peer Reviewed: 14/07/2021 - Accepted for Publication: 15/07/2021

\section{Check for updates}

\section{ABSTRACT}

Hypertension (HTN) is a major public health issue worldwide, because of its high prevalence and concomitant increase in the risk of disease. In the contemporary situation Hypertension is the most critical disease in the world. If we focus on the present situation then we can see that due to rapid globalization we are facing Hypertension. Due to rapid modernization, people are leading more stressful lives. As a result, hypertension is one of the widespread disorders which came across in practice. Ab. India is labelled as the global capital of hypertension. Nowadays, not only lifestyle disorders are becoming more common, but they are also affecting younger populations. Hence, the population at risk shifts from $40+$ to maybe $30+$ or even younger. Hypertension results from a variety of reasons like stress, obesity, genetic factors, overuse of the salts in the diet and ageing etc. As we all know, $H y$ pertension is called a silent killer because it rarely exhibits symptoms before it damages the heart, brain or kidney. Though a lot of potent antihypertensive drugs are available today in modern medicine, none of them is free from untoward effects. The principal focus of Ayurveda is on maintaining good health and adopting a healthy way of life. In Ayurveda, there is no description of such a single disease that can resemble hypertension. As per Ayurvedic principles, in case of an unknown disease, the physician should try to understand the nature of the disease through Dosha, Dushya and Samprapti; then should initiate the treatment. So, it becomes our prime concern to understand hypertension thoroughly with an Ayurvedic perspective. Hypertension (HTN or HT), also known as High blood pressure or arterial hypertension, is a chronic medical condition in which the blood pressure in the arteries is persistently elevated. Hypertension is one of the major causes of cardiovascular morbidity and mortality 
worldwide. It is a global health problem affecting people of different ethnicity and ages around the world. It is an asymptomatic medical condition in which systemic arterial blood pressure is elevated beyond the normal value.

Keywords: High Blood Pressure, Lifestyle disorders, Silent killer.

\section{INTRODUCTION}

Hypertension (HTN or HT), also known as high blood pressure or arterial hypertension, is a chronic medical condition in which the blood pressure in the arteries is persistently elevated. Hypertension is one of the major causes of cardiovascular morbidity and mortality worldwide. It is a global health problem affecting people of different ethnicity and ages around the world. The basis for diagnosing and managing hypertension is the measurement of BP, which is routinely used to initiate or rule out costly investigations and long-term therapeutic interventions. Inadequate measurement methodology or use of inaccurate $\mathrm{BP}$ measuring devices can lead to overdiagnosing and exposure to preventable cardiovascular disease (CVD). The World Health Organization (WHO) has identified India as one of those nations that are going to have most of the killer because it rarely exhibits symptoms before it damages the heart, brain, or kidney. ${ }^{1}$ It is an asymptomatic medical condition in which systemic arterial blood pressure is elevated beyond the normal value. Hypertension is an important worldwide public health challenge and remains a major cause of morbidity and mortality worldwide. ${ }^{2}$ Hypertension is called a silent killer, non-communicable chronic disease because it rarely exhibits symptoms before it damages vital organs like the kidney, brain, or heart. Nearly $63 \%$ of total deaths in India are due to non-communicable diseases which affect $45 \%$ of people in the 40-69 age group. Raised blood pressure is among the most important risk factors for CVDs.Moreover, it remains poorly controlled due to low awareness about hypertension, lack of appropriate care through primary care and poor follows up. About $26.4 \%$ of the world adult population in 2000 had hypertension and $29.2 \%$ were projected to have this condition by $2025 .{ }^{3}$

The following factors made me go for a clinical study on Essential hypertension:
- Essential hypertension is one of the common complaints of this modern era and is the silent killer of mankind. - It is a risk factor for all clinical manifestations of atherosclerosis. - It is an independent predisposing factor for heart failure, coronary artery disease, stroke, renal disease, and peripheral arterial disease and rarely exhibits symptoms before it damages vital organs like the kidney, brain or heart.

- Hypertension (HTN or HT), also known as high blood pressure or arterial hypertension, is a chronic medical condition in which the blood pressure in the arteries is persistently elevated. Hypertension is one of the major causes of cardiovascular morbidity and mortality worldwide. It is a global health problem affecting people of different ethnicity and ages around the world. It is an asymptomatic medical condition in which systemic arterial blood pressure is elevated beyond the normal value. Hypertension is a chronic and often asymptomatic medical condition in which systemic arterial blood pressure is elevated beyond normal. As such, the heart is forced to work harder to overcome the increased systemic pressure to deliver blood to tissues, which puts strain on the heart and arteries. Over the period, the additional strain leads to cardiovascular dysfunction and is a primary contributing cause of congestive heart failure, myocardial infarction, pulmonary embolism, cerebral aneurysm, and kidney failure. ${ }^{4}$

\section{Types of Hypertensions-}

There are two types:

1. Primary or essential hypertension (97-98\%) has no clear underlying cause but appears to be the result of the interplay of complex genetic and environmental factors.

2. Secondary hypertension (2-3\%) is caused by a specific underlying mechanism usually involving the kidneys or endocrine system. 
Factors Affecting Blood Pressure- These include Vessel Elasticity, Blood Volume, Cardiac Output, Peripheral Resistance. Peripheral resistance depends upon blood viscosity, vessel diameter and vessel length. -The tension exerted on the wall of arteries by the strength of the contraction of the heart is called "Blood Pressure". 5 Several other factors and conditions may play a role in the development of hypertension such as smoking, overweight or obesity, lack of physical activity, excessive salt intake, alcohol consumption, stress and family history of high blood pressure. ${ }^{6}$ There is a close connection between our body and our mind. If there is a psychological factor affecting a medical condition, it is important to treat the psychological problem as well as the medical problem. If there is stress-related hypertension treatment should be planned accordingly. As per Ayurve$d a$, Vata is the regulator and stimulator of Mana (mind). One should not neglect this basic principle while treating hypertension. ${ }^{7}$

\section{Ayurvedic Perspective:}

Description of Hridaya and processes of Rasa Vikshepana (circulation) by Vyana Vayu is helpful to understand the disease. Though the exact nomenclature of the disease to some extent is controversial, the signs and symptoms of the disease can be understood in terms of Dosha, Dushya, Strotasa, etc. Looking at Hypertension from this perspective, we can assume that vitiated Vata Dosha is the main cause of the disease, as the Dhatu Gati (Rasa Gati) or Vikshepa is achieved by Vayu itself. ${ }^{8}$ Pitta and Kapha complement the effect of vitiated Vata and support the progress of the disease with Rasa, Rakta (whole blood) being the main mediator of vitiation. This suggests the involvement of Tridosha in Hypertension. Inference of previous research work done is that hypertension is nothing but a 'Vata Pradhan Tridoshaja Vyadhi', be greatly influenced by Mana. Therefore, it may be considered as Sharir and Manas Roga (Ubhayashrita Vyadhi). Sharir and Satva (Mana) have been designated as the habitats of Vyadhi by Acharya Charaka. ${ }^{9}$

\section{Factors involved in Hypertension} DOSHA:
Prana Vayu: In modern science, the functions of the nervous system have been described as a description of the Prakriti Prana Vayu. 'Hridaya Dhruka; (i.e. Dharana of Heart) the function of Prana Vayu can be correlated with the vagal inhibition of the nervous system. ${ }^{10}$ In addition to this, the vasomotor centre controls the blood pressure by the autonomic nervous system; similarly, Prana Vayu also controls the regulation of blood pressure by controlling Vyana Vayu. So, pathology of Prana Vayu can cause abnormality of heart as well as vessels.

Vyana Vayu: Vyan Vayu is said to be responsible for various kinds of movements in the body. ${ }^{11}$ With the help of Vyan Vayu, the heart contracts and propels blood (Rasa Rakta Dhatu) continuously all over the body. So, it suggests the involvement of Vyana Vayu in the regulation of blood pressure.

Samana Vayu: According to Sharangadhara after the digestion process 'Samana Vayu' helps in the transportation of Rasa into the heart and from there it circulates in the whole body. ${ }^{12}$ Thus Samana Vayu has an important role in circulation.

Apana Vayu: Vitiation of Apana Vayu hampers the excretion of the Purisha and Mutra affecting homeostasis which may affect blood pressure. From the above fact, it can be concluded that Apana Vayu also plays a role in the regulation of normal blood pressure. ${ }^{13}$

Avalambaka Kapha: Normal rhythm, contractility, and tone of cardiac muscles can be correlated with functions of Avalambaka Kapha. ${ }^{14}$ Thus; it keeps the heart in a healthy state and enhances its continuous pumping capacity.

Dushya: In the circulatory system Aahar rasa, Rasa Dhatu and Rakta Dhatu are the entities that circulate all over the body. In the context of blood pressure, Rasavaha and Raktavaha Srotasas are important as they are related to 'Rasa-Rakta Samvahana'. Annavaha Strotas gets vitiated due to untimely intake of a large quantity of unwholesome food and impairment of Agni (digestive capacity).

Rasa Dhatu- Acharya Charaka in Vimanasthana described various factors responsible for Rasavaha Strotas Dushti, viz. excessive intake of Guru (heavy), 
Shit (cold), excessively unctuous food, and constant worry.

Rakta Dhatu-Raktavaha Strotas gets vitiated due to intake of food and drinks which are irritant, unctuous, hot and liquid; excessive exposure to sunlight and fire. ${ }^{15}$

Agni: Agni is an important factor in the pathogenesis of all the diseases Agni Dushti occurs at two levels Jatharagni Mandya and Dhatwagni Mandya. Atimatrashana (excessive diet), Viruddhashana (intake of food having opposite properties), and Adhyashana (intake before the digestion of previous food) are the factors that cause Jatharagni Mandya. It will affect all other Agni viz. Sapta Dhatvagni and Panchamahabhutagni. Jatharagni Mandya will cause Ama formation which results in Strotorodha and vitiation of all Doshas. It will ultimately increase peripheral resistance and can lead to hypertension. Atherosclerotic changes in vessels can be an outcome of chronic Agnimandya and Ama. Acharya Charaka has already described Dhamani Pratichaya as one of the Nanatmyaja diseases of Kapha dosha. ${ }^{16}$

Mana: In Ayurveda Pradnyaparadha and Asatmendriyartha Samyoga is considered as the root causes for every disease, which indicate the involvement of the psyche. Manas Bhavas like Chinta (worry), Krodha (anger), Bhaya (fear) etc. plays an important role in the pathogenesis, progression, and prognosis of disease as well as response to the treatment of the disease. ${ }^{17}$ This fact reveals that Mana is also involved in hypertension and the disease should be considered psychosomatic. Modern medical science also considers the involvement of the psyche as a causative factor for hypertension.

Samprapti (Pathogenesis of hypertension): Most of the mechanisms associated with secondary hypertension are crystal clear and completely understood. However, those associated with essential hypertension are far less understood. The pathogenesis of hypertension takes place at both the physical and psychic level one at a time or simultaneously depending upon the Dosha-Dushya Sammurchhana. Agnidushti results in Ama formation and subsequent Dhatudushti (Rasa and Rakta). This leads to KhaVaigunya i.e. obstructive pathology in channels. The Ama production results in Strotorodha (obstruction) and thus partially blocks the normal Rasa Rakta circulation which further vitiates Vyana Vayu. This obstructed Vyana Vayu leads to forcible blood flow in the blood vessels causing increased resistance, thereby increasing blood pressure. ${ }^{18}$

Chikitsa (Treatment): Treatment of Hypertension should be planned according to Dosha and Dushya involved in pathogenesis. Manasa Bhavas like Chinta, Krodha, Bhaya, etc., plays an important role in the pathogenesis, progression, and prognosis of the disease, and also affect the response to the treatment. Hence, the type of therapy recommended should be one that can pacify these disturbed Manasika Bhavas.

Panchakarma: Abhyanga (Massage) - Sarvanga Abhangya with specially formulated oils helps to increase elasticity and flexibility. It corrects and enhances the blood flow healthily. a- Vaman and Virechan (Emesis and purgative therapy) - If the patient is having Uttam Bala and having the mild or moderate type of hypertension without any other complications then Shodhana procedures like Vaman, Virechan can be advised according to Dosha Pradhanya. b- Basti (Medicated enema): - Basti therapy is specially designed for Vata disorders. It is also called Ardha Chikitsa by stalwart Acharyas. According to Dushti Dosha and Rugna Bala, Karma, Kala or Yoga Basti can be advocated.

Diet: Dietary modification is very important to prevent the development of hypertension or potentially combat and reduce high blood pressure. Lowering sodium intake (especially from table salt) reduces excessive water retention, which helps maintain normal blood pressure. ${ }^{19}$ Excessive use of sodium chloride is toxic and damaging to arteries and other tissues, which may initiate atherosclerosis and lead to hypertension. Adopting a high potassium diet helps rid the renal system of excess sodium and restore sodium/potassium balance. Acharya Charaka has also considered Lavana as a substance not to be used in excessive quantity for a longer duration. ${ }^{20}$ Additional dietary changes beneficial for reducing blood pressure include adopting a diet that is rich in fruits, 
vegetables, whole grains and low-fat dairy products, reducing consumption of refined sugar and heavily processed food, reducing caffeine intake, and limiting alcohol consumption. ${ }^{21}$

Yoga: Stress reduction from practising meditation, yoga, and other mind-body relaxation techniques can lower blood pressure. ${ }^{22}$ Yoga is formulated for many reasons and health restoration is one of them. Shavasana, Sukhasana Dhanurasana, Makarasana, Vajrasan, along with the regular practice of Pranayama are found to be very useful for lowering blood pressure in normal as well as hypertensive individuals if performed accurately and adopted as a lifestyle. ${ }^{23}$ According to Bruhadaranyaka and Chhandogya Upanishads the ultimate aim of Pranayama and Yogic techniques is to control Prana. This target is difficult to achieve, but mental peace and relaxation thus achieved could be used as a therapeutic tool. Patel and others in Britain have shown that meditation and prayer techniques lower blood pressure on a short term and long-term basis. This factor may be important in the primary prevention of coronary atherosclerosis. On a metabolic level, it causes a decrease in various biochemical inducers and aggravators of atherogenesis. Hrudayotpatti: Acharya Sushruta has described 'Shonit Kapha Prasadajam Hridayam', which means while the development of Garbha in the uterus, the heart is formed by the purest portion of Rakta (blood) and Kapha. ${ }^{24}$ These originating constituents should be considered while treating cardiac ailments. Drugs acting on these constituents can offer more reliable results.

Other strategies effective at reducing blood pressure - These include weight reduction and regular aerobic exercises such as brisk walking, jogging running etc. Weight loss reduces the resistance burden on the vascular system, and regular exercise improves blood flow and helps to reduce resting heart rate and blood pressure. Discontinuing tobacco use in any form has also been shown to lower blood pressure. The tar of smoke and the injurious components of the tobacco produce hardening of blood vessels (arteriosclerosis), plaque in the blood vessels, which can make narrowing of the inner diameter of blood ves- sels. Abstaining from cigarette smoking reduces the risks of stroke and heart attack associated with hypertension. Alcohol consumption can enhance fat accumulation. ${ }^{25}$ Obese people often have hypertension (elevated blood pressure) because the additional blood vessels in their adipose tissue increase their total blood vessel length. Resistance to blood flow through a vessel is directly proportional to the length of the blood vessel. The longer a blood vessel, the greater is the resistance. An estimated $650 \mathrm{~km}$ (about 400 miles) of additional blood vessels develop for each extra kilogram $(2.2 \mathrm{lb})$ of fat. ${ }^{26}$

\section{CONCLUSION}

In the current situation despite taking modern medicine patients with hypertension increasing drastically. In the contemporary situation, everyone is looking towards Ayurveda in a search of ideal and safe treatment. Hence, getting the perfect management of hypertension without any side effects is a need of the present era. In the Ayurveda equilibrium of Doshas, Dhatus, Malas and Agni are considered as a healthy state of an individual. In nutshell, we can say that while observing hypertension through Ayurvedic spectacle one or more of the following three possibilities should be considered. 1. Pathophysiological changes in the form of vitiation of Dosha (Vata, Pitta and Kapha), Dhatu and Mala Dushti. 2. Psychological changes i.e. disturbances at the level of Mana (Manovaha Strotas Vikara). 3. Structural changes as complications of long-term hypertension on various organs like heart, blood vessels, kidney etc. After a thorough study of literature and fundamentals in both Ayurveda and Modern medicine, it is concluded that the Ayurvedic approach to treat disease according to its Samprapti (pathogenesis) is very practical and should not be overlooked. This review of hypertension showed that the disease can be well managed by following Pathya Apathyaas mentioned in Ayurveda (avoidance of the etiological factor). Considering the detailed conceptual part, we can say that Ayurveda describes the appropriate lifestyle and diet management called Aahar and Vihar for maintaining homeostasis and thereby preventing hypertension. Proper 
medication as per Ayurvedic guidelines (along with proper Aahar, Vihar and Yoga) will control blood pressure without any untoward effects. An additional benefit of Ayurvedic management is the absence of hazardous effects which is very important given the global acceptance of Ayurveda.

\section{REFERENCES}

1. WHO report of Prevention and control for Cardiovascular diseases, 20012002, available from http://www.sld.cu/./pdf/./international cardiovascular disease statistics. page 2

2. Moser M, Roccella EJ, The treatment of hypertension: a remarkable success story, J Clin Hypertens (Greenwich), 15, 2013, 88-91.

3. Whelton P.K, Global burden of hypertension: an analysis of worldwide data, The Lancet, 365 (9455), 2005, 217223.

4. S.D. Pierdomenico et al. "Prognostic value of different indices of blood pressure variability in hypertensive patients." American Journal of Hypertension. 2009, 22(8):842-7.

5. Tabers Cyclopedic Medical Dictionary, 20th edition, 2005, Page no 268.

6. Siddhart N. Shah. API Textbook of Medicine, 7th Edition, 2003.

7. Charaka Samhita', Vaidya Yadavaji Trikamaji Acharya, Chaukhmba surbharati prakashana, reprint 2000, Ch. Su.12.

8. Charaka Samhita', Vaidya Yadavaji Trikamaji Acharya, Chaukhmba surbharati prakashana, reprint 2000, Ch. Su. 18/49.

9. Ibid-13, 44-46.

10. Rajshekara Sanapeti, Clinical Study on the effect of Takradhara in the Essential Hypertension.

11. Vriddha Vagbhata, Ashtanga Samgraha (Shashilekha commentary of Indu), edited by Shivaprasad Sharma, 2nd ed, Chaukhamba Sanskrit series office, Varanasi, 2008, Sutrasthana 20/6: 156

12. Ibid 16

13. Sharangadhara, Sharangadhara Samhita, edited by Shailaja Shrivastava, Reprint edition, Chaukhamba Orientalia, Varanasi, 2009, Poorvakhanda 6/8, 52.

14. Swami Sadashiva Tirtha, The Ayurveda Encyclopedia, edited by RC Uniyal, 5thedition, Ayurveda holistic centre press, USA, 2005, pg.360.

15. Ranjitray Desai, Ayurvediya Kriyasharira, 5thedition, Baidyanath Ayurveda Bhawan Ltd., Allahabad, 2003, pg. 741.

16. R.K. Sharma et. Al., Caraka Samhita Volume 2, Chaukhamba Sanskrit Series Office, Varanasi, Third edition 1994, Ch. Vi. 5/12-14,pg. 178-179.
17. R.K. Sharma et. Al., Caraka Samhita Volume 1, Chaukhamba Sanskrit Series Office, Varanasi, Fourth edition 1995, Ch. Su. 20/17, pg. 370

18. Dhananjay Patel et.al, Role of Manas Bhavas in the etiopathogenesis of Uccharaktachapa (EHT) and its management with Medhya Rasayana and Shi

1. Vithalani Lalitkumar V. Et; Al: Hypertension AnAyurvedic Perspective

2. Rodhara, MD thesis, GAU, Jamnagar, 2003.

19. Viadya Yadunandan Upadhayaya editor Ashtanghridyam Sootrsthana ch.13/25, 8th ed. page 111 Chaukhamba Prakashan, Varanasi.

20. L.J. Appel et al. "A clinical trial of the effects of dietary patterns on blood pressure." New England Journal of Medicine. 1997, 336(16):1117-24.

21. Dr Brahmanand Tripathi, Charak Samhita Vol.1, Chaukhambha Surbharati Prakashan, Varanasi, 2009, Vimanasthana 1/15; page-660

22. R.J. Padwal et al. "The 2010 Canadian Hypertension Education Program recommendations for the management of hypertension: Part 2 - Therapy." The Canadian Journal of Cardiology. 2010,26(5):249-258.

23. M.V. Rainforth et al. "Stress Reduction Programs in Patients with Elevated Blood Pressure: A Systematic Review and Meta-analysis." Current Hypertension. 2007, 9(6):520-8.

24. Susruta, Susrutasamhita, Vaidya Yadavaji Trikamaji Acharya, Chaukhamba Surabharathi Prakashan, Varanasi, 7th edition 2008, Sharirsthana 4/3

25. http://www.yoga-india.net/wpcontent/uploads/2014/04/High-BloodPressure-YogaMinami.pdf

26. Principles of Anatomy and Physiology 13th edition G. Tortora, B. Derrickson (Wiley, 2012) BBS, pg 815.

\section{Source of Support: Nil \\ Conflict of Interest: None Declared}

How to cite this URL: Anshika Rao et al: Hypertension: An Ayurvedic Perspective. International Ayurvedic Medical Journal \{online\} 2021 \{cited August 2021\} Available from: http://www.iamj.in/posts/images/upload/1748_1753.pdf 